\title{
Recruitment of Foreign Members by Islamic State (Daesh): Tools and Methods
}

\author{
Bozorgmehri Majid ${ }^{1,2}$ \\ ${ }^{1}$ Imam Khomeini International University, Qazvin, Iran \\ ${ }^{2}$ York University, Toronto, Canada \\ Correspondence: Bozorgmehri Majid, York University, Toronto, Ontario, Canada. E-mail: \\ bozorg_majid@yahoo.com
}

Received: June 11, 2018

Accepted: October 10, 2018

Online Published: November 30, 2018

doi:10.5539/jpl.v11n4p51

URL: https://doi.org/10.5539/jpl.v11n4p51

\begin{abstract}
In the era of technology, Islamic State has shown that it is be able to link the radical reading of Islam with the modernity of the internet and social media to increase its scope of influence to all borders of the world. The social networks were very significant medium for Daesh.

This article targets as its main concern, to analyze deeply the global strategy of "Islamic State" (IS) for recruitment of foreign warriors by looking at the methods through which the outstanding plan is carried out. It tries also to elaborate the communication strategy of the Islamic State besides the contents of the messages which have been broadcasted. By borrowing Malet's conceptions, the paper schemes its theoretical bases and by relying on the own Islamic State sources, it tries to find and elaborate the required data.
\end{abstract}

Keywords: foreign fighters, Daesh, Middle East, recruitment, Islam

\section{Introduction}

\subsection{Problematic Debate}

The exciting reasons for moving towards to terrorist groups vary greatly including religious, psychosocial, sociological, and political characteristics. The so-called "Islamic State of Iraq and Syria" or Daesh has taken excessive usage of the Internet and online social media sites for broadcasting its words and leading the youth to move to the Caliphate territory for engaging in combat - fighting side-by-side with other Jihadist warriors, or to join the Islamic State by carrying out a supportive role - which is likely the role carved out for the Young females who are convinced to enter Islamic State. IS propaganda was more often targeted at Westerners and more specifically designed for the "Millennial generation."

Obviously, social media has been recognized to be enormously an effective device for Daesh and is exactly suited for lot of audience whom it is intending to target.

As an illegal group seeking to mobilize new members and communicate defiant messages, ISIS has advanced communication policies dependent on a combination of simple and new media facilities. It has used billboards, murals and mosque sermons to communicate with local people, while constructing a likely sophisticated control on the internet to communicate with its audience abroad. This article aims as its major concern, to analyze deeply the global strategy of "Islamic State" (IS) for recruitment of foreign members by looking at the methods through which the outstanding plan is carried out. It tries also to elaborate the communication strategy of the Islamic State besides the contents of the messages which have been broadcasted. As an illegal terrorist group, IS has focused great attention on controlling information and using available media to recruit fighters or send messages.

\subsection{Previous Literature}

Works and researches relating to the terrorist recruitment could be classified into two categories; the first tries to describe merely methods and tactics exercised by terrorist groups for recruitment, the second focuses on the Islamic State's policies. Without denying value of the previous literature analyzing the terrorist recruitment in general, it should be reclaimed that most of them included vague all- encompassing recruitment operations, instead of precise methods. Some work has recognized that a great bulk terrorist recruitment takes place over social media (Comey, 2015). 
Additional, by the internet as an accessible technique to target recruits, terrorist organizations so can target the young groups who use the internet most often for browsing (Weimann, 2006).

Although a large number of general works on the ISIS is recorded but the researchers who have worked on the recruitment process are rare. (Stenger, 2017) Peresin, for example, tried to investigate into reasons for radicalization of women by examining the exposed source information on social media channels of identified Islamic State adherents. (Peresin, 2015). Erelle studied terrorist recruitment approaches firsthand by entering the jihadist recruitment sections herself. She described the diverse means that terrorists communicate with potential recruits. Using social media, she connected with a jihadist warrior of the IS who convinced her to move to Syria. (Erelle, 2015)

Gates and Podde have stated that the social media has been the most strong and successful soft device for recruitment of foreign members by the Islamic State. (Gates, 2015)

As an eminent researcher, Anderson through his paper "Cubs of the Caliphate" shows some psychological aspects of recruitment and the abuse of the child in the IS. (Anderson, 2016)

Besides of other scholar, Ristori explains generally the strategies of IS in foreign recruitment.(Ristori.2016) With confession on the precious value of all previous works, the gape of a comprehensive analysis remains yet, because most of the works tried to concentrate on one case, one site, one group or sometimes just one member. By this article, we intend to present a more comprehensive analysis, not limited to single factor or aspect, with considering the multi effective variables having overlapping nature.

\subsection{Theoretical Framework}

Charlie Winter conducted research on recruitment of foreign fighters. According to his theory, there are three aspects needed to fuel the process of recruitment. All these aspects are necessary to convince someone to join Jihad. These aspects are an echo chamber, propaganda, and the enlister. The echo chamber is a small group of people with whom a potential recruit can discuss the propaganda. The propaganda is all the content the person reads and watches, gradually realigning this person's moral norms. The enlister provides practical information according to traveling or weighing the risks. (Winter, 2015: 7) Malet's theory could be considered as one relative covering model for research. Malet's main claim is that "recruiters tell potential new members that their common is under existential peril and that their involvement is indispensable for the survival of their population and, eventually, themselves. (Malet, 2013)

In designing his framework, Malet offers some theoretical explanations. As the begetting researcher in recognizing the concept of 'foreign warriors' as an outstanding kind of phenomenon, he outlines them as "non-citizens of conflict states who join rebellions during civil wars." (Nelson, 2017) He explains that the description eliminates:

1) Militants participating in a foreign state's military that are ordered into the conflict,

2) Foreigners who join a foreign state's military,

3) Forces of private security companies.

It ought to be noted that in our case, we mean ISIS, the rebellious group fights a lot of authorities, combats other competing insurgent groups like the PKK, the FSA or Al- Nusra, and are not limited by national frontiers.

For our article, we interpret the concept of 'insurgency' more broadly, as Salehyan presents in his work "Rebels without Borders", to theoretically include civil conflicts that expand beyond national boundaries and against multiple groups. (Salehyan, 2009)

The configuration certainly holds true for the IS as well, where the organization specifically declares that foreign warriors not join for the sake of loot, monetary compensation, the prospect for sex slaves, etc. (Nelson, 2017)

ISIS notifies newcomers that it cannot guarantee the provision of any of such benefits. Islamic State articulates for the newcomers that 'martyrdom' will be the most honorable imaginable ending reward for the emigration and the waging of jihad. According to Mason, potential fighters almost never join the fight for ideological reasons; instead, individuals join an insurgency group, such as the Islamic State, based on selective incentives (Mason, 2004: 48). This theory is even more applicable to potential foreign recruits because these foreigners, living in relatively safe western countries, are not influenced by violent coercion and threats to their lives. These selective incentives can consist of hard benefits or soft benefits. For example, a feeling of community, security, and honor are considered soft benefits, while a monthly pay check, a house, and maybe even slaves are considered hard benefits. (Lippink, 2017) This research tries to find narratives that might present and promote these benefits to the potential recruits. But as a final consideration, the recruitment of Islamic State is classified in a very complicated package, including various motivations from completely religious ones up to excited emotions to violence or even sexual needs. 


\section{Data and Analysis}

\subsection{Gradual Growth of Foreign Recruitment}

There are different reported statics relating to overall ISIS recruitment. According to Anderson, foreign warriors comprise half of IS's members, which include 4000 Westerners. (Anderson, 2016) As of January 26, 2015, around 20,730 people have traveled from ninety countries in order to fight for Islamic State, most of these people hailing from Arab nations. In Europe, France (1,200), the UK (500-600), and Germany (500-600) have produced the biggest numbers of foreign warriors. (Neumann, 2016)

The Soufran Group (TSG) through an updated assessment in 2015 reported the number of foreign fighters in Syria at upwards of thirty thousand from over 100 countries. (The Soufran, 2015)
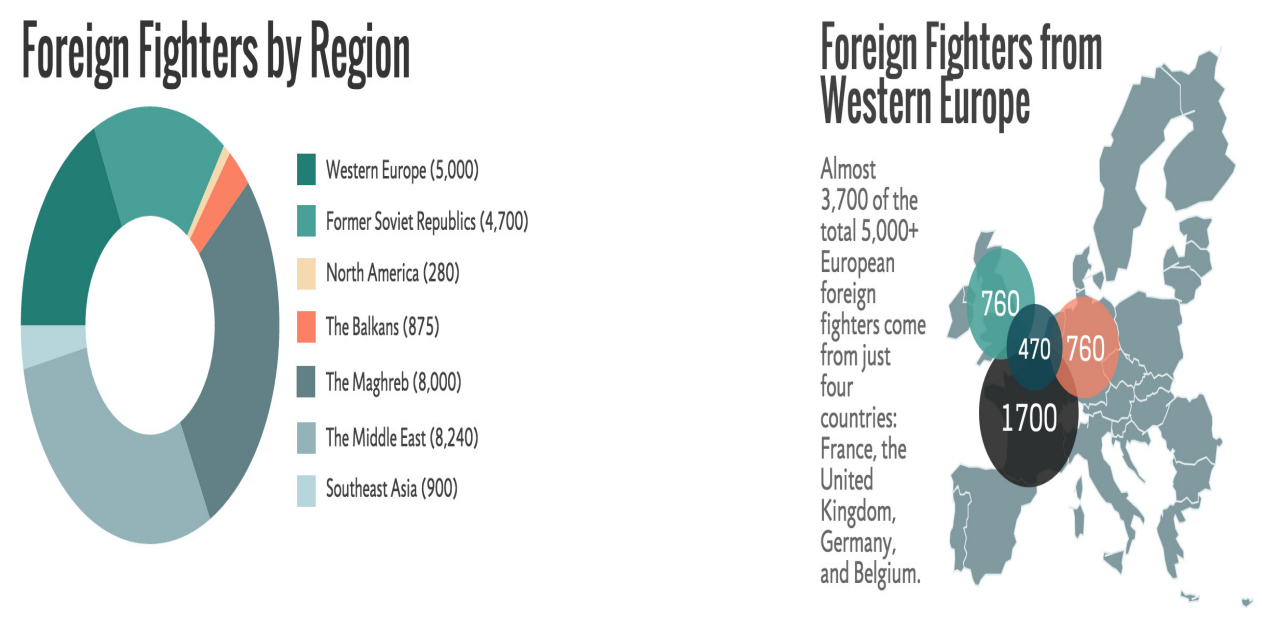

Graph 1. Number of foreign fighters by region and from Western Europe (TSG. 2015)

Table 1. Number of top foreign fighter nationalities (TSG. 2015)

\section{Top Foreign Fighter Nationalities}

\begin{tabular}{|c|c|}
\hline Tunisia & \\
\hline Saudi Arabia & 2,500 \\
\hline Russia & 2,400 \\
\hline Turkey & 2,100 \\
\hline Jordan & 2,000 \\
\hline
\end{tabular}


Table 2. Foreign fighter growth 2014-2015 (The Soufran. 2015)

\section{Foreign Fighter Growth}

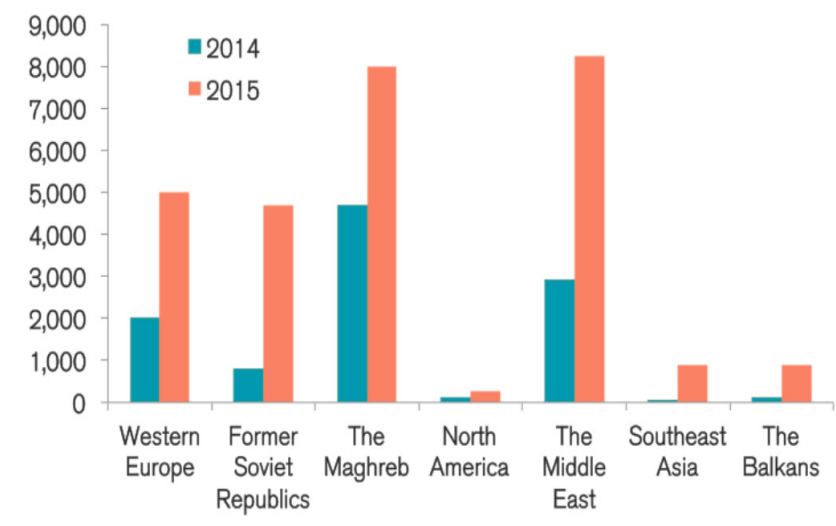

Relaying on Kozaric report, there is a considerable progressive rise of recruitment from 2011 up to 2015. (Kozaric, 2017)

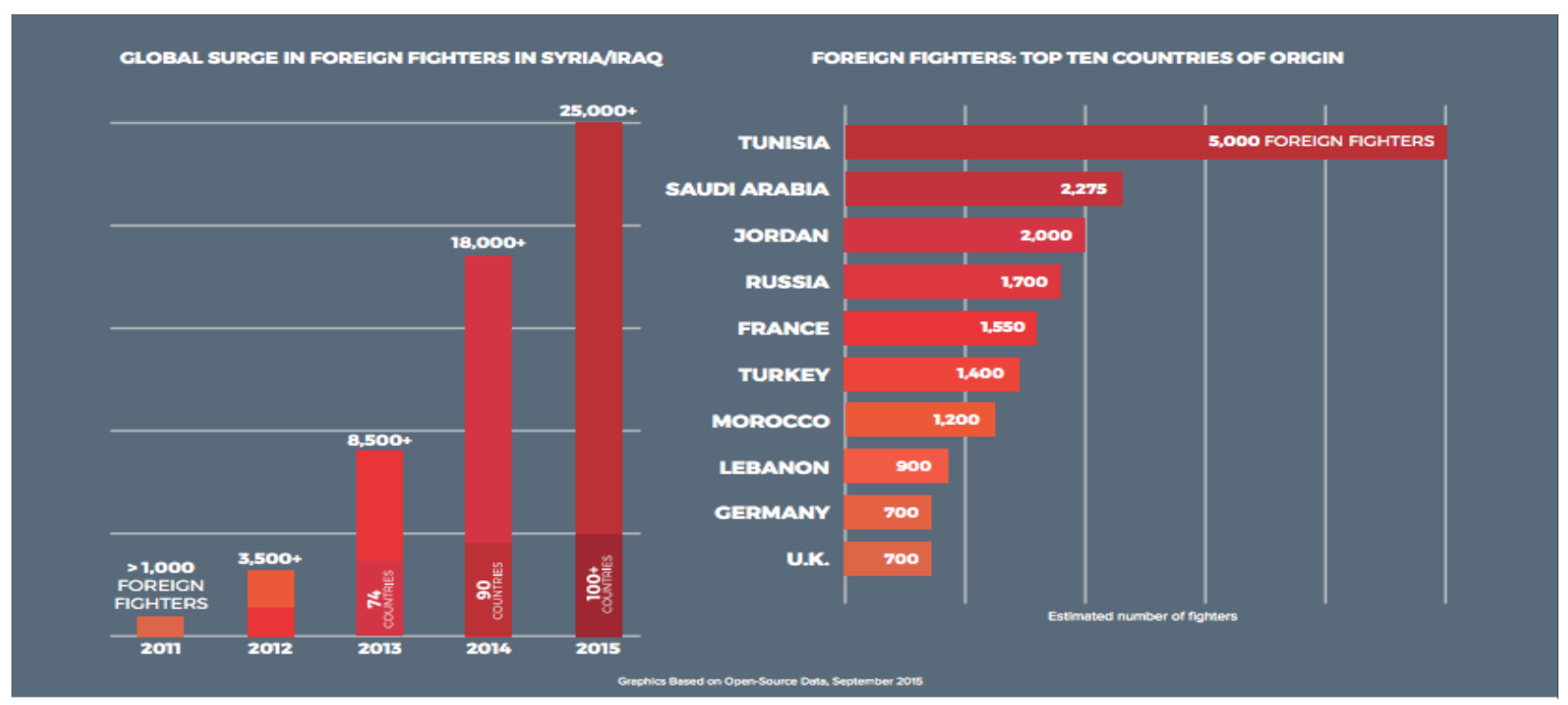

Graph 2. Estimation of total number of foreign warriors arrived in Syria and Iraq 2011-2015 (Kozaric, 2017) 

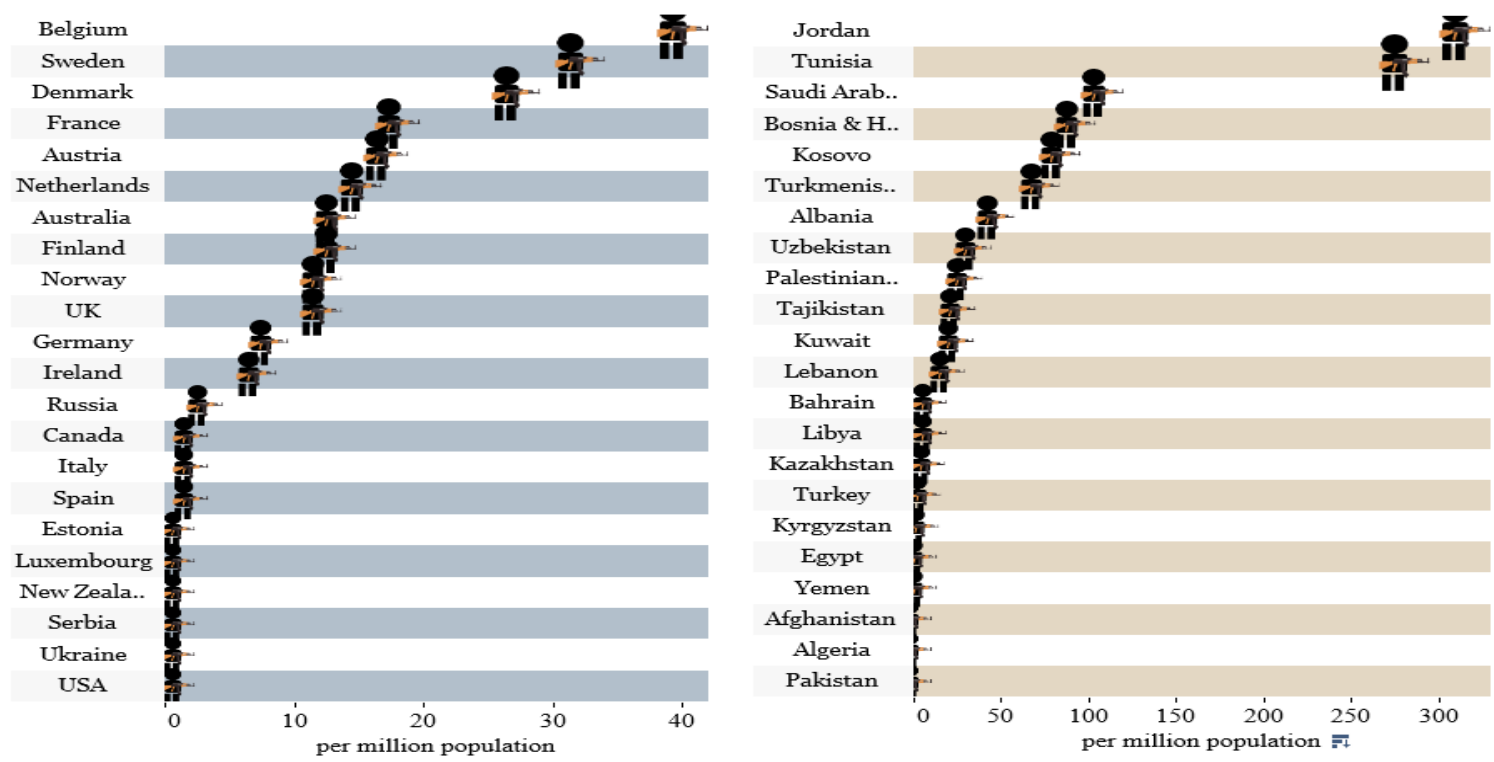

Graph 3. Combatants per million populations, Western States and the rest (Page.2015:21)

Lang states nearly the same statistics. (Lang, 2016) Among these various statistics, we can declare definitely the undeniable growth of the foreign recruitment of IS during the short time of 2011-2015.

\subsection{Methods and Tools}

Al-Hayat Media Center was responsible for much of the group's marketing and recruitment. The main stated goal was to "convey the message of the IS in different languages with the goal of unifying Muslims under one flag." (Masi, 2014)

As an illegal organization trying to mobilize new recruits and communicate rebellious conceptions, Islamic State has settled communication policies dependent on a combination of primitive and new media tools and the use of social media outlets. (Masi, 2014)

\subsubsection{Mass Media}

To achieve its goals, IS relies on market division and diversification of media. IS's utilization of social media and digital major scheme plays a significant role in the worldwide broadcasting of propaganda, and conscription. ISIS was using the internet in two ways. The first, which served to initially attract likely new members, was for marketing purposes. It contains formal marketing, such as their official journal, Dabiq, as well as the videos released by al-Hayat Media Center; but also more informal marketing, usually spread through social media sites like Twitter and Tumblr, which include policies that any 21 st century company uses nowadays, like the use of hashtags and memes, as well as photos with verses from the Quran, demonizing the West, or promoting a picture of unfair treatment over the Muslims everywhere in the

globe.

The second way which Daesh was using the internet for recruiting its foreign warriors was the most intensive and important part of the process i.e. personal recruitment. (Ristori, 2016)

\subsubsection{Social Media Outlets}

Islamic State recruiters have developed social media channels to "field questions about joining" the group, a process which resembles an "online version of religious seminar." (Masi, 2014)

CEP has documented as IS recruiters exploit online platforms such as Twitter, (Berger, 2014) Facebook, YouTube, Tumblr, Ask.fm, and Askbook, to publicize and recruit for Islamic State. Recruiters apply instant-messaging services such as Telegram, Wickr, KiK, and YikYak to provide advice about logistical issues-such as transportation and finances-regarding the journey to Syria. (Bacchi, 2014) 


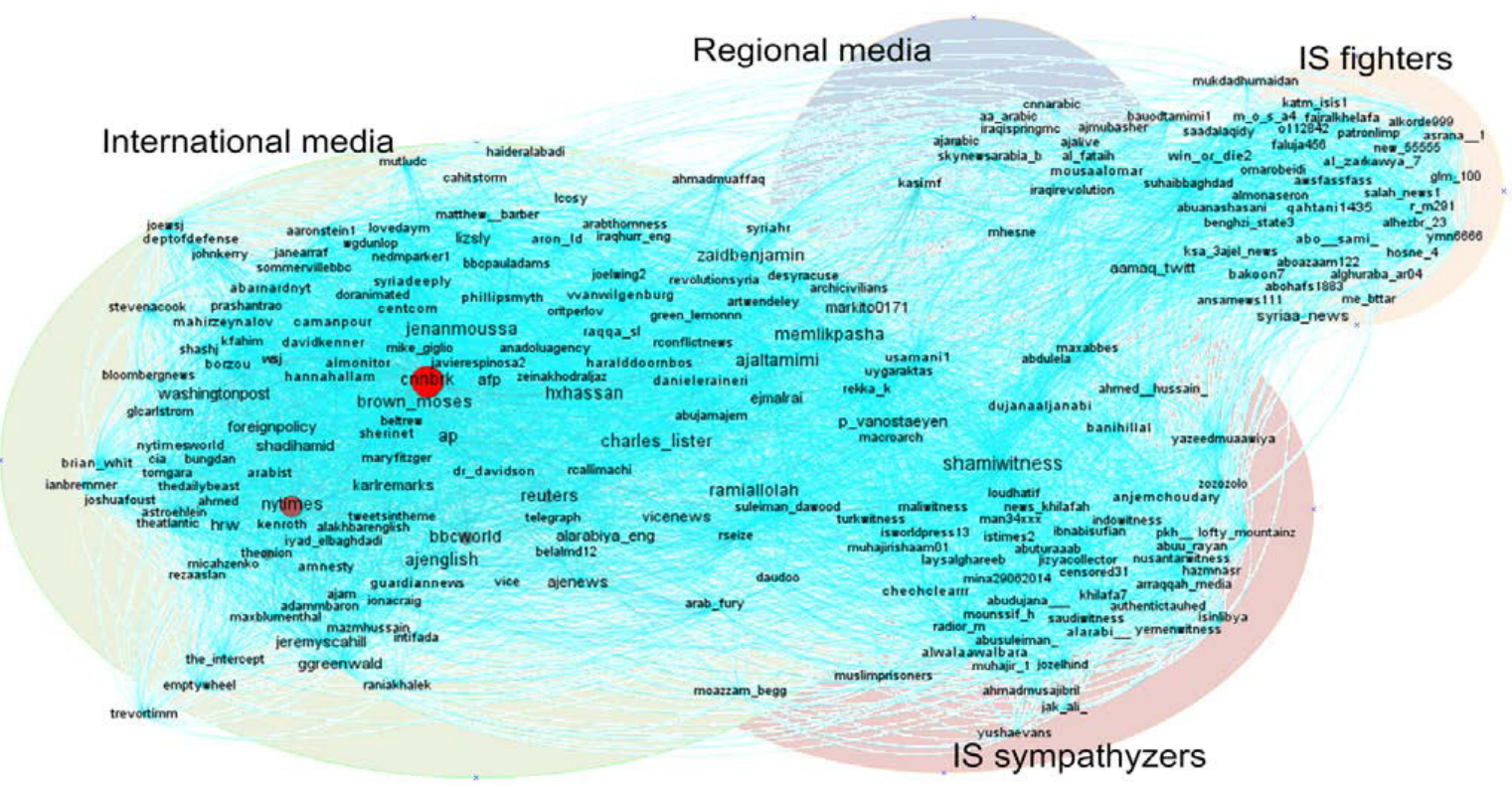

Figure 1. Multi-sided Twitter networks of users mentioned in@shamiwitness tweets (Chatfield, 2015)

\subsubsection{Online Media, TV and Journals}

The main media arms of IS include the al-Hayat Media Center, the al- Furqan, al- I'tisaam and Ajnad Media Foundations, and the A'maq News Agency.

Debates have been produced in English, Arabic, Russian, Urdu, Turkish, and even Hebrew. (Williams, 2016) The IS's first advertising journal is titled Dabiq. Dabiq bills itself as "a periodical journal fixing on the topics of tawhid (unity), manhaj (truth-seeking), hijrah (migration), jihad (holy war) and jama'ah (community). It will also contain photo reports, current events, and informative articles on matters relating to

IS." Rumiyah is a new religious public journal that is less size than Dabiq. It emphases on putting forward the group's political and theological stance, explaining why opposition to the group is heretical and gloating about terrorist attacks. The title refers to Rome, which the IS wishes to triumph over, both as a political goal but also as a symbolic one. (Haris, 2014) The al-Hayat Media Center is the IS arm that produces the conceptual meanings of videos and films. In July 2014, al-Hayat circulated eleven releases in English which were shot in high definition with proficient editing and consistent branding. (Schori Liang, 2015)

Al-Hayat Media Center also produces material aimed at recruiting. It produces a HD propaganda series known as "Mujatweets," which portrays daily life, a kind of reality show from fighters and testimonials from Western warriors who are already in Syria and Iraq. (Mujatweets Episode \#1. 2014)

According to the Middle East Media Research Institute (MEMRI), "the purpose [of the Mujatweets] is to show that life under ISIS rule is peaceful and normal.

(Middle East Media...2014)

The IS message is also spread by unofficial global activists who help circulate propaganda, known as tweeps, fanboys and fangirls. In September 2014, footage of an IS style videogame emerged. In the trailer for this fanboy-produced game based on the popular Grand Theft Auto series, players are seen dressed as IS warriors and tasked with shooting police and blowing up military goals. (Schori Liang, 2015)

\subsection{Contents of Propaganda}

The IS tries to achieve three key objectives through its communication strategy: legitimization, mobilization and terrorizing.(Al-Qarawee, 2016: 101) According to Bergen`s Study, an assessment of ISIS propaganda illustrates a diverse mixture of motivations and subjects that IS utilizes for its recruiting policy.

These include:

- Opposition to the Assad regime;

- The spiritual value of contributing in jihad; 
- The holy duty to work in the Islamic territory; - Anger at Western civilization;

- Hostilities to American foreign policy;

- Glorifying terrorist actions carried out in the West to encourage others to

violent activities; (Bergen, 2016)

But the motivations and main factors of recruitment could be classified into some categories i.e. sociological, political, religious and psychological factors. (Stenger, 2017)

\subsubsection{Sociological Messages}

The outlined hate against Western people serves as a sociological stimulator for the young particularly for female young to join ISIS. The detestation is caused by the feeling of racial discrimination and of disregarding. (Deeyah, 2015).

As Husna Haq, reported they try to offer youth a sense of self identity. "IS particularly preys on Western youth who are disillusioned and have no sense of future or belonging to society."(Haq, 2015)

\subsubsection{Political Messages}

There are various interpretations and assessments on the IS `s complex propaganda apparatus which has a political nature.

Zelin's investigation of a sample of one week's worth of propaganda (including reports, radio streams, notices, and videos) for seven days from 18th up to 24th April 2015 shows that IS`s propaganda circles about six themes; military, governance, preaching, justice by Sharia, advancement of the caliphate, and enemy attack. (Zelin, 2015)

Nelson focuses his analysis on 13 issues of Dabiq from 5 July 2014 up to 19 January 2016. It should be noted that the subjects of Dabiq were most prepared for a foreign audience. (Nelson, 2017)

Table 3. Topics of Dabiq- From 5-Jul-2014 to 19-Jan-2016 (Nelson, 2017)

\begin{tabular}{|c|c|c|c|c|}
\hline & ssue & Date & Issue Title & Number of Pages \\
\hline 1 & 1 & 5-Jul-14 & The Return of the Khilifah & 50 \\
\hline 2 & 2 & $27-J u l-14$ & The Flood & 44 \\
\hline 3 & 3 & $10-$ Sep-14 & A Call to Hijrah & 42 \\
\hline 4 & 4 & 11-Oct-14 & The Failed Crusade & 56 \\
\hline 5 & 5 & 21-Nov-14 & Remaining and Expanding & 40 \\
\hline 6 & 6 & 29-Dec-14 & Al-Qa'idah in Waziristan: A Testimony from Within & 63 \\
\hline 7 & 7 & $12-F e b-15$ & From Hypocrisy to Apostasy: The Extinction of the Grayzone & 82 \\
\hline 8 & 8 & 30-Mar-15 & Shariah Alone Will Rule Africa & 68 \\
\hline 9 & 9 & 21-May-15 & They Plot and Allah Plots & 79 \\
\hline 0 & 10 & 13-Jul-15 & The Law of Allah or the Laws of Men & 79 \\
\hline 1 & 11 & 9-Aug-15 & From the Battles of Al-Ahzab to the War of Coalitions & 66 \\
\hline 2 & 12 & 18-Nov-15 & Just Terror & 66 \\
\hline 13 & 13 & 19-Jan-16 & The Rafidah from Ibn Saba? to the Dajjal & 56 \\
\hline
\end{tabular}

By distinguishing 8 messages, Nelson tries to illustrate the weight and the value of each message in the IS's propaganda. Each conscription note was given a number, a title label, and a small descriptive description, such as like:

- Superior and Victorious

- Islam is superior and will be inevitably victorious in combating its enemies. 
- Utopianism

- The Islamic State is a sole utopia for faithful Muslims.

- A New World System

- ISIS is trying to substitute western civilization with a socio- political model fixed on Islam.

- Religious Mission

- Obedience to God is synonymous of spiritual salvation, and it is a precondition for being accepted by ISIS.

- Legitimacy- ISIS`s actions follow the pure creeds of holy Islamic orders, and are justified merely based on Islamic values.

-Muslim Defense. Muslims have been oppressed and/or existentially threatened, and the Islamic State fights to defend Muslims.

- Thrill, Excitement, Adventure. Joining ISIS's war and its other actions is perceived as some exciting, thrilling, and/or fulfilling capability.

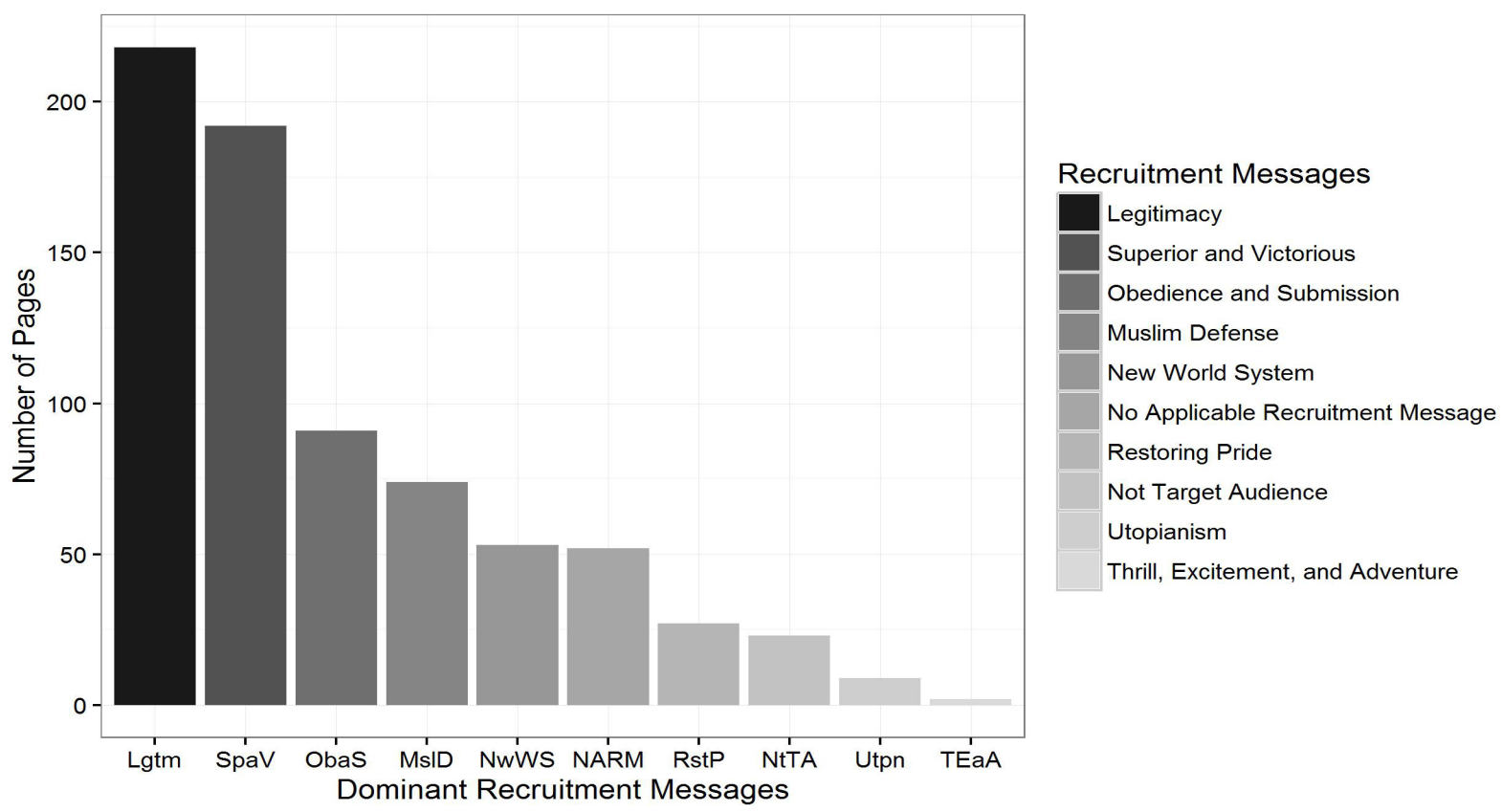

Figure 2. The weight of various messages in IS`s Propaganda (Nelson, 2017)

\subsubsection{Religious Messages}

There are some religious narratives which had enough capacities for mass foreign recruitment.

\subsubsection{Hijrah}

The most important religious message which enjoy an effective influence on foreign recruitments is the principle of Hijrah. Global engagement requires movement to and from the places where Daesh wants support. Therefore, part of the recruitment strategy advertises Hijrah, or Jihad by emigration. Daesh emphasizes the correlation between Hijrah and Jihad Daesh simplifies Islamic history and uses stories about Muslims currently living among non-Muslims who have put themselves at the mercy of non-believers. This setting gives rise to a narrative that encourages Muslims to prepare themselves for migration to the safe and newly established 'Caliphate'. (The NATO StratCom ...2016)

The notion of hijra towards to the caliphate is principal for ISIS' religious tradition. For instance, in the 3th edition of Dabiq, ISIS claimed so that "canceling hijrah which is the path to jihad, could be considered as a treacherous issue. (Gartenstein-Ross, 2016: 12 )

\subsubsection{The Caliphate as a Holy Utopia}

The dominant narration in IS' propaganda is that the caliphate is a sacred and holy utopia.(Gartenstein-Ross, 2016: 16) 


\subsubsection{Driving a Wedge between Muslims and the West}

One another narration which ISIS has used to mobilize Muslims in the West is one that pits the caliphate and the "camp of Islam" against the West and the "camp of kufr".(Gartenstein- Ross, 2016: 16)

\subsubsection{Psychological Messages}

The psychological feature of Daesh's recruitment is important for analyzing it as a whole and its success in recruiting new members from all of various territories, Middle East or Europe. IS's success in recruiting people globally through psychological methods is extraordinary. Much of Daesh's ability, particularly in the West, can be attributed to its worldwide effect. IS`s recruitment structure is designed by professionals in offering their potential members with promises of precisely what they feel necessary for the lifetime. They are able to provide a tight-knit society for those who feel alone; some holy utopia for whom following up their objectives in lifetime; some feelings of moral power for those who are not fully persuaded that they want to pass their lifetime in the West. (Ristori. 2016)

For some foreign warriors, the holy and religious elements in conscription are also being substituted by more social components such as peer pressure and role modeling. Furthermore the romantic outlook of contribution in a significant and exciting event

may play a role. Most of suicide fighters realize themselves more as heroes than as martyrs. (Europol Public Information, 2016: 3).

An important percent of foreign warriors have been diagnosed with mental problems before linking to Daesh. (Europol Public Information, 2016: 6)

\section{Conclusion}

In our era of technology, Islamic State has demonstrated that it is be able to link the radical reading of Islam with the modernity of the internet and social media to increase its scope of influence to all borders of the world which never before reached by the fanatical and religious clusters. We know today that social networks were very significant medium for Daesh. These networks could be categorized into two kinds: Closed jihadist and popular open networks. The first is the specialized social media that appear for a period of time to circulate ideas and manipulated conceptions as well as to host debates on issues of concern. The latter embraces networks and platforms such as Twitter, Facebook and Instagram, Telegram, Imo, WhatsApp, Duo, Messenger, Viber and etc... The way that the Islamic State was using media has been extremely structured and organized. IS was also creating a huge amount of propaganda on social media and through movies and glossy online magazines. It has many audiences, including its own recruits, the enemy, the western media, and also its potential recruits. Daesh has established a three-tier hybrid communication arrangement: a central core, provincial information offices, and broad members and supporters. At its core, it formed four central media outlets to provide enormous propaganda pieces that align with core objectives and manage dissemination operations - al Hayat, al-Furqan, al- Itisam, and Ajnad. For al Hayat, recruiting was the major goal. Texts broadcasted vary according to their targeted audience and goals. By the discourse and communication content, they seek to attain numerous strategic aims that, for the purpose of this study, can be divided into three leading approaches: legitimization, mobilization and terrorizing. An examination of Islamic State's publicity illustrates some various mixture of motivations and subjects that IS uses them for the recruitment.

They include:

- Divine benefit of joining the jihad;

- The holy mission to be and pass your lifetime in the caliphate and help it and sacrifice your future for it.

- Hate the Western world;

- Resistance against U.S.A worldwide policy;

- Sanctifying terrorist actions accomplished in the West to encourage others to violent activities;

- A new happy living near to family with a good job which ensures well payment as well as free medical care;

- The "coolness," and even romance, of sacred jihad. The concentration of its propaganda was not merely limited to political and religious aspects, but maybe more on the psychological dimensions of the foreign young from Asian and Western nations.

Indeed, among the virtually atmosphere in the world nowadays, ISIS could be considered as the best winner who had the high potentials to use minimum for obtaining maximum. The success of IS in its policies of foreign recruitment proves clearly that the process of social and political integration in the western countries has not been 
enough successful, especially regarding to the second or third generation of the immigrant people. The main causes of such failure in social and political integration deserve to be considered as the interesting topics for future research.

\section{References}

Al-Qarawee, H. H. (2016). The Media, Methods and Messages of the Islamic State's Communication Strategy. Giusto. Hedwig "Daesh and the terrorist threat: from the Middle East to Europe" FEPS - Foundation for European Progressive Studies. Brussels, Belgium.

Anderson, K. (2016). "Cubs of the Caliphate". The Systematic Recruitment, Training, and Use of Children in the Islamic State. Retrieved from https://www.ict.org.il/Article/1629/Cubs-of-the-Caliphate\#gsc.tab=0

Bacchi, U. (2014). ISIS agents in London dispatching gullible teenage jihadi brides to Syria. International Business Times, December 19, 2014. Retrieved from http://www.ibtimes.co.uk/isis-agents-london-dispatching-gullible-teenage-jihadi-brides-syria-1480246

Barrett, R. (2015). Foreign Fighters in Syria [White paper], The Soufan Group, June 2014. Retrieved April 25, 2015, from http://soufangroup.com/foreign-fighters-in-syria/

Bergen, P. (2016). ISIS Online: Countering Terrorist Radicalization \& Recruitment On the Internet \& Social Media. U.S. Senate Committee on Homeland Security, Permanent Subcommittee on Investigations. Testimony by Peter Bergen. July 6, 2016.

Berger, J. M. (2014). How ISIS Games Twitter. Atlantic, Retrieved June 16, 2014, from http://www.theatlantic.com/international/archive/2014/06/isis-iraq-twitter-social-media-strategy/372856/

Carter, J., Maher, S., \& Neumann, P. (2014). \#Greenbirds: Measuring Importance and Influence in Syrian Foreign Fighter Networks. Retrieved November 11, 2014, from http://icsr.info/wpcontent/uploads/2014/04/ICSR-Report-Greenbirds-Measuring-Importance-and-Infleuncein-Syrian-Foreign- Fighter-Networks.pdf

Chatfield, A. T. (2015). Tweeting propaganda, radicalization and recruitment: Islamic state supporters multi-sided. Twitter networks. https://doi.org/10.1145/2757401.2757408

Clarion Project. (2014). The Islamic State's (ISIS, ISIL) Magazine. Clarion Project. Retrieved September 10, 2014, from http://www.clarionproject.org/news/islamic-state-isis-isil-propaganda-magazine-dabiq

Comey, J. (2015, July). The complexity of today's global threat environment. Paper presented at Aspen Security Forum. Aspen, CO.

Deeyah, K. (2015). For Isis women, it's not about 'jihadi brides': it's about escape. Retrieved from https://rethinkingislamwithsultanshahin.wordpress.com/2015/06/26/for-isis-women-its-not-about-jihadi-bri des-its-about-escape/

Erelle, A. (2015). In the skin of a jihadist: A young journalist enters the ISIS recruitment network. New York, NY: Harper Collins Publishers.

Europol Public Information. (2016). Changes in modus operandi of Islamic State terrorist attacks. Review held by experts from Member States and Europol on 29 November and 1 December 2015. The Hague, 18 January 2016.

Gartenstein-Ross, D., Nathaniel, B., \& Bridget, M. (2016). The Islamic State's Global Propaganda Strategy. The International Centre for Counter-Terrorism - The Hague (ICCT) ICCT Research Paper. https://doi.org/10.19165/2016.1.01

Gates, S., \& Sukanya, P. (2015). Social Media, Recruitment, Allegiance and the Islamic State. Perspectives on Terrorism, 9(4).

Haq, H. (2015). ISIS Excels at Recruiting American Teens: Here Are Four Reasons Why. The Christian Science. Monitor, October 22, 2014. Retrieved April 25, 2015 from http://www.csmonitor.com/USA/USA-Update/2014/1022/ISIS-excels-at-recruiting-American-teens-Here-ar e-fourreasons-why-video

Haris, D. (2014). The Islamic State's (ISIS, ISIL) Magazine. Retrieved from https://clarionproject.org/islamic-state-isis-isil-propaganda-magazine-dabiq-50/ 
Kozaric, E. (2017). Exploring the demand side of foreign rebel recruitment. A comparative Case Study of Al Qaeda in Iraq (2004-2008) and the Islamic State (2012-2016). Master Thesis in Peace and Conflict Studies Spring 2017. Department of Peace and Conflict Research Uppsala University.

Lang, H., \& Muath, A. W. (2016). The Flow of Foreign Fighters to the Islamic State .Assessing the Challenge and the Response. Center for American Progress.

Leppink, D. (2017). Recruitment Propaganda of the Islamic State. Recruiting Narratives in the Islamic State's Propaganda.

Malet, D. (2013). Foreign Fighters Transnational Identity in Civil Conflicts. Hardcover. https://doi.org/10.1093/acprof:oso/9780199939459.001.0001

Masi, A. (2014). ISIS Twitter, Facebook account: James Foley video highlights disturbing, but effective recruitment campaign. International Business Times, August 20, 2014. Retrieved from http://www.ibtimes.com/isis-twitter-facebook-account-james-foley-video-highlights-disturbing-effective-16 60544

Mason, D. T. (2004). Caught in the Crossfire: Revolution, Repression, and the Rational Peasant. Rowman \& Littlefield Publishers.

Nelson, J. M. (2017). Foreign Fighter Recruitment Messaging and the 'Islamic State. Utah State University. DigitalCommons@USU. All Graduate Theses and Dissertations Graduate Studies 2017. Logan, Utah.

Page, R. (2015). ISIS and the sectarian conflict in the Middle East. Research Paper 15/16 19 March 2015. House of Commons. Library.

Peresin, A. (2015). Fatal Attraction: Wester Muslimas and ISIS. Perspectives on Terrorism, 9(3).

Ristori, C. M. (2016). Online Jihad: ISIS's Foreign Recruitment Strategies - Who, What, and How? Advanced Seminar in Global Studies.

Salehyan, I. (2009). Rebels without Borders Transnational Insurgencies in World Politics. Ithaca: Cornell University Press. https://doi.org/10.7591/9780801459214

Schori Liang, C. (2015). Cyber Jihad: Understanding and Countering Islamic State Propaganda. GCSP Policy Paper 2015/2 - February 2015. Geneva Center for Security Policy.

Stenger, H. (2017). Gendered Jihad - Recruitment Strategy of the Islamic State. Master Thesis.

The NATO StratCom Centre of Excellence. (2016). Daesh Recruitment How the Group Attracts Supporters. Prepared by the Nato Strategic Communications Centre of Excellence.

The Soufran Group. TSG. (2015). Foreign Fighters. An Updated Assessment of the Flow of Foreign Fighters into Syria and Iraq. Retrieved from http://soufangroup.com/wpcontent/uploads/2015/12/TSG_ForeignFightersUpdate_FINAL3.pdf.

Weimann, G. (2006). Terrorist Dot Com: Using the internet for terrorist recruitment and mobilization. In J. F. Forest (Ed.), The making of a terrorist: Recruitment, training and root causes (pp. 53-65). Westport, CT: Praeger Security International.

Williams, L. (2016). Islamic State propaganda and the mainstream media. February 2016. The Lowy Institute for International Policy.

Winter, C. (2015). Documenting the Virtual "Caliphate". Quilliam Foundation. "Islamic State Propaganda, Key Elements of the Group's Messaging." Terrorism Monitor, 13(12).

Zelin, A. Y. (2015). Picture Or It Didn't Happen: A Snapshot of the Islamic State's Official Media Output. $\begin{array}{lllll}\text { Perspectives } & \text { on } & \text { Terrorism, } & 9(4) . & \text { Retrieved }\end{array}$ http://www.terrorismanalysts.com/pt/index.php/pot/article/view/445

\section{Copyrights}

Copyright for this article is retained by the author(s), with first publication rights granted to the journal.

This is an open-access article distributed under the terms and conditions of the Creative Commons Attribution license (http://creativecommons.org/licenses/by/4.0/). 